\title{
Articles
}

\section{EFFICIENCY OF POLISH AGRICULTURE BETWEEN 1998 AND 2015}

\author{
WOJCIECH JÓZWIAK
}

\begin{abstract}
In several years leading up to and in the year of the accession, Polish agriculture has seen a rapid growth in the agricultural production efficiency, followed by its slow decline. The article identifies the reasons for this phenomenon. In the first of these subperiods, there was considerable economic freedom and an increase in support for farms, granted mainly by the domestic funds. In the years after 2004, the situation changed. The amounts of aid funds increased, so did the environmental and consumer health and animal welfare requirements to be met by farmers being beneficiaries of subsidies. In addition, larger farms also reduced their economic activity due to the degression in subsidy rates. It is also probable that some agricultural producers have been mainly focused on using subsidies and this phenomenon was accompanied by a decrease in interest in improving the agricultural production efficiency. Some arguments contained in the article were based on estimates. They are rationally substantiated, but according to the author, the article should be considered as preliminary analysis of the topic.
\end{abstract}

Keywords: efficiency, agriculture, production efficiency.

JEL codes: Q11, Q21, Q28.

Prof. dr hab. Wojciech Józwiak, Instytut Ekonomiki Rolnictwa i Gospodarki Żywnościowej - Państwowy Instytut Badawczy, Zakład Ekonomiki Gospodarstw Rolnych; ul. Świętokrzyska 20, 00-002 Warszawa (wojciech.jozwiak@ierigz.waw.pl). ORCID iD: 0000-0002-5358-261X. 


\section{Introduction}

The preliminary findings showed that Polish agriculture, in a period of several years prior to, in the year of and some years after accession, has been subjected to processes atypical of a country with intermediate level of economic development.

Table 1

Resources of utilised agricultural area, labour inputs and production costs in constant prices per PLN 1 million of the value of revenues in Polish agriculture in 2000-2015

\begin{tabular}{|c|c|c|c|c|}
\hline \multirow{2}{*}{ Types of resources, inputs and costs } & \multicolumn{4}{|c|}{ Years } \\
\hline & 2000 & 2005 & 2010 & 2015 \\
\hline Utilised agricultural area (ha) & 222.4 & 191.1 & 175.7 & 159.0 \\
\hline Employment per FTE & 32.3 & 27.5 & 22.6 & 21.2 \\
\hline Costs of intermediate consumption ${ }^{\mathrm{b}}$ (PLN thousand) & 735.5 & 653.8 & 686.3 & 744.5 \\
\hline \multicolumn{5}{|c|}{ Year 2000 = 100,0 } \\
\hline Utilised agricultural area & 100.0 & 85.9 & 79.0 & 71.4 \\
\hline Employment per FTE & 100.0 & 85.1 & 70.0 & 65.6 \\
\hline Costs of intermediate consumption ${ }^{\mathrm{b}}$ & 100.0 & 88.9 & 93.3 & 101.2 \\
\hline
\end{tabular}

${ }^{a}$ Revenues have also been calculated in constant prices.

${ }^{\mathrm{b}}$ Calculated together with depreciation costs of fixed assets.

Source: own findings made based on the data taken from: GUS (2017a); Eurostat (access date: 17.10.2017); GUS (2017b) and Rachunki... (RER) as of 9.12.2016.

The loss in the utilised agricultural area and in the number of the employed per unit of production volume was not accompanied by an increase, but rather, by a decrease in production costs of intermediate consumption (Table 1). An important reason for this phenomenon could be the increased agricultural production efficiency.

The objective of this paper is to present the size of the above-mentioned phenomenon and to identify its reasons as well as the reasons for its disappearance in the second part of the analysed period.

\section{Method of analysis}

The agricultural efficiency was measured by a ratio of the value of income to the costs of intermediate consumption. On the side of revenues, the following were included: the value of agricultural production, receipts from agricultural production services provided to other farms and the value of homemade products prepared using own agricultural products. On the other hand, the intermediate consumption included the costs of: seeds, seed potatoes and own and purchased seedlings; energy carriers and lubricants; mineral fertilisers and soil improvers, plant protection products, agricultural services, own and purchased feedstuffs, medicinal products for animals, veterinary services; repair and maintenance of machinery and buildings, as well as the depreciation of fixed assets.

The data was sourced from the economic accounts for agriculture (EAA), which are satellite accounts with respect to some national accounts. Since 1998, 
the Institute of Agricultural and Food Economics - National Research Institute has kept them in cooperation with the Central Statistical Office (Główny Urzad Statystyczny, GUS) for the needs of the European Commission. These accounts covered the period between 1998 and 2015. The EAA set of figures covering this period, as of 9 December 2016, has provided nominal amounts of the value of agricultural revenues and costs of intermediate consumption.

The nominal amounts of revenues and costs of intermediate consumption taken from the EAA were converted into constant prices. For this purpose, the authors used GUS materials collected since 1995. What was determined on the basis of those materials, were fixed base indices of changes in selling prices of agricultural products and in prices of means of production purchased by agricultural producers in between 1998 and 2015, assuming that the prices of 2015 are equal to " 1 ". Thus established figures are contained in Tables 1 and 2 of the Annex.

The amounts of income and costs of intermediate consumption in subsequent years, as calculated in constant prices of 2015, were then converted into average five-year amounts, so as to make it easier to establish their trend changes. The amounts of both indicators, calculated in this way, become the basis for the calculations describing the calculations of changes in the agricultural efficiency ratio in the analysed period.

\section{Results of the findings and determining the reasons for changes}

Table 2 presents the figures determining the components of the agricultural efficiency ratio between 1998 and 2015.

Table 2

Average five-year amounts of revenues and costs of intermediate consumption of Polish agriculture, determined in constant prices (of 2015) and dynamics of their change

\begin{tabular}{cccccc}
\hline \multirow{2}{*}{$\begin{array}{c}\text { Average } \\
\text { five-year } \\
\text { amounts }\end{array}$} & $\begin{array}{c}\text { Mid-years } \\
\text { of five-year } \\
\text { periods }\end{array}$ & \multicolumn{2}{c}{ Revenues } & \multicolumn{2}{c}{ Costs of intermediate consumption } \\
\cline { 3 - 6 } $1998-2002$ & 2000 & 80.5 & - & 65.7 & - \\
$1999-2003$ & 2001 & 80.5 & 100.0 & 63.7 & 96.9 \\
$2000-2004$ & 2002 & 82.1 & 102.0 & 63.4 & 99.5 \\
$2001-2005$ & 2003 & 83.5 & 101.7 & 62.5 & 98.6 \\
$2002-2006$ & 2004 & 84.2 & 100.8 & 62.2 & 99.5 \\
$2003-2007$ & 2005 & 86.1 & 102.2 & 63.6 & 102.2 \\
$2004-2008$ & 2006 & 86.5 & 100.5 & 64.5 & 101.4 \\
$2005-2009$ & 2007 & 86.5 & 100.0 & 64.2 & 99.5 \\
$2006-2010$ & 2008 & 86.8 & 100.3 & 64.6 & 100.6 \\
$2007-2011$ & 2009 & 87.5 & 100.8 & 65.6 & 101.5 \\
$2008-2012$ & 2010 & 86.9 & 99.3 & 64.9 & 98.9 \\
$2009-2013$ & 2011 & 87.8 & 101.0 & 64.9 & 100.0 \\
$2010-2014$ & 2012 & 88.6 & 100.9 & 64.9 & 100.0 \\
$2011-2015$ & 2013 & 89.4 & 100.9 & 66.6 & 102.6 \\
\hline
\end{tabular}

Source: own findings made based on the results of economic accounts for agriculture (EAA) as of 9.12.2016 and materials taken from GUS studies. 
In the analysed period, the value of income increased by $11.1 \%$. This increase took place in ten five-year periods analysed, in two - there was a stagnation and in only one - a decline. But then, the costs of intermediate consumption declined until 2004. However, in the subsequent years, they increased to such a level that the overall increase in the amount of the costs over the entire analysed period was $1.4 \%$. However, the figures in Table 3 point to changes in the national agricultural efficiency ratios in the individual years of the analysed period.

Table 3

Average five-year sizes of the national agricultural efficiency ratios in 1998-2015

\begin{tabular}{cccc}
\hline $\begin{array}{c}\text { Average five-year } \\
\text { amounts }\end{array}$ & $\begin{array}{c}\text { Mid-years } \\
\text { of five-year periods }\end{array}$ & Ratio size $^{\mathrm{a}}$ & Previous period=100 \\
\hline $1998-2002$ & 2000 & 122.5 & - \\
$1999-2003$ & 2001 & 126.4 & 103.2 \\
$2000-2004$ & 2002 & 129.4 & 102.4 \\
$2001-2005$ & 2003 & 133.6 & 103.2 \\
$2002-2006$ & 2004 & 135.6 & 101.5 \\
$2003-2007$ & 2005 & 135.4 & 99.8 \\
$2004-2008$ & 2006 & 134.1 & 99.0 \\
$2005-2009$ & 2007 & 134.7 & 100.4 \\
$2006-2010$ & 2008 & 134.4 & 99.8 \\
$2007-2011$ & 2009 & 133.4 & 99.2 \\
$2008-2012$ & 2010 & 133.9 & 100.4 \\
$2009-2013$ & 2011 & 135.3 & 101.0 \\
$2010-2014$ & 2012 & 136.5 & 100.9 \\
$2011-2015$ & 2013 & 134.2 & 98.3 \\
\hline
\end{tabular}

a Amounts of revenues in PLN per PLN 100 of the costs of intermediate consumption.

Source: own calculations prepared based on the figures in Table 3 .

The average of the size of the national agricultural efficiency ratio in the last analysed five-year period was by $10.7 \%$ higher than the first five-year period, but the increase was not even. In the first five periods, the value of the ratio was growing continuously from 122.5 to 135.6 . Thus, the increase amounted to 13.1 percentage points (pp) and its annual average rate was $2.5 \%$. In the next nine five-year periods, the value of the ratio varied between 133.4 and 136.5. A comparison of the average three-year values from the beginning and the end of this period indicates a weakly outlined downward trend in the value of the analysed ratio. Back then, the value of the ratio decreased by 1.2 , which means that the average annual rate of this decrease was $0.1 \%$.

An upward trend in the value of the agricultural efficiency ratio in the years prior to and in the year of accession was probably initiated in 1994, before farms gained 
access to low-cost loans financed from the national budget. In the years preceding the accession, also the funds from the SAPARD and PHARE programmes, cofinanced by the European Union, became available ${ }^{1}$, but their direct impact should not be oveestimated.

Moreover, because of a collapse of the state-owned farms and some agricultural production cooperatives and also due to generation change, 1.4 million ha of UAA between 1996 and 2002 changed their owners. Therefore, 2.8 thousand large agricultural enterprises could appear and the share of farms held by natural persons with an area of 15-50 ha of UAA could increase by about 25\% (Józwiak, 2014).

From the panel of 5,387 farms which between 2005 and 2007 kept accounts for the Polish FADN, the author selected those with profit ${ }^{2}$ and presented their characteristics against a background of other farms. The results of the account are included in Table 4. The farms with profit had the value of assets about twice higher than those without profit, but what is important is that their production efficiency ratio was by $18.7 \%$ higher.

Table 4

Characteristics of the panel of natural persons' farms with profit a against a background of the farms without profit (average figures from 2005-2007)

\begin{tabular}{lcc}
\hline \multirow{2}{*}{ Ratios } & \multicolumn{2}{c}{ Farms } \\
\cline { 2 - 3 } & with profits & others \\
\hline Number of analysed farms & 1,716 & 3,671 \\
Value of assets (property), including land, in PLN thousand & 940 & 465 \\
Average size of the efficiency index of analysed farms & 142.7 & 120.2 \\
\hline
\end{tabular}

a Profit was calculated as a difference of agricultural income and contractually calculated payment for own labour. For details please refer to footnote 2, below.

Source: own findings prepared based on the study by Józwiak (2014).

Based on agricultural accounting data of 1999, figures from the national agricultural census of 1996 and similar figures for 2005-2007, it was estimated that the national number of farms with profit, together with those without profit but with the extended reproduction of assets (property), and therefore the total number of farms not drifting but economically active increased in 1996-2006 by 68 thousand, i.e. by $64.1 \%$ (Table 5). In the same period, the number of other natural persons' farms decreased by 366 thousand, i.e. by $20.1 \%$. The latter group included the farms selling the whole or the majority of their final production and those producing mainly or exclusively for the needs of the holders' families. Since none of them gained any

\footnotetext{
${ }^{1}$ Special Accession Programme for Agriculture and Rural Development and Poland and Hungarian Assistance for Restructuring of their Economics.

${ }^{2}$ Profit was calculated as a difference of agricultural income and contractually calculated payment for own labour. Payment for labour of one person employed full-time on their own farm was calculated at a parity rate (payment for managerial labour, labour devoted to marketing and executive labour), and the remaining labour input was valued according to market payment for hired labour in agriculture.
} 
profit, their equity was not covered. This was the reason why on the farms called "others" a permanent depreciation of assets and, what is more, family work unit payment were lower than the parity rate and average market payment for hired labour in agriculture. In this situation, some successors did not want to take over such farm from its previous user.

Table 5

Estimated change in the number of farms in Poland with agricultural production and the area of more than 1 ha of UAA differing in terms of their economic activity in 1996-2007 (in thousands)

\begin{tabular}{lcc}
\hline \multicolumn{1}{c}{ Type of farms } & \multicolumn{2}{c}{ Years } \\
\cline { 2 - 3 } & $1999^{\mathrm{a}}$ & $2005-2007^{\mathrm{b}}$ \\
\hline $\begin{array}{l}\text { With and without profit but } \\
\text { with positive reproduction of assets }\end{array}$ & 106 & 174 \\
Other & 1807 & 1444 \\
\hline
\end{tabular}

${ }^{\text {a }}$ Figures estimated based on the agricultural accounting data of 1999 figures (IERiGŻ, 2000) from the national agricultural census of 1996 (GUS, 1997).

${ }^{\mathrm{b}}$ Averages for 2005-2007 estimated based on data taken from the study of Józwiak (2014) and figures from the national agricultural census of 2002 (GUS, 2003).

Source: own findings.

Another important factor that led to a rapid increase in the agricultural efficiency index in several years prior to accession and in the year of accession, was a significant reduction in the area of UAA. The farms quit cultivating marginal UAA, for example with poor soils, and some UAA was allocated for other purposes. The total loss in UAA in 2002-2010 amounted to 1,396 million ha (GUS, 2012c), i.e. $8.3 \%$. This phenomenon has only been inhibited in the following years. There are no figures demonstrating the impact of this loss on the value of the analysed index, so the author refers to an estimate. The paper assumes that crops cultivated on the worst quality land were those whose efficiency ratio was as in the case of winter rye. Since the average value of this ratio in 2009-2010 was 107.2 (Augustyńska-Grzymek, Cholewa and Żekało, 2011), it was possible to determine that the average country-wide ratio increased due to the fact that between 2002 and 2010 there was a reduction in the national area of UAA, from $129.4^{3}$ to 134.1 , i.e. by $3.6 \%$.

Changes taking place in animal breeding also affected the value of the national agricultural efficiency ratio. Many farms, mainly smaller ones, quit small-scale rearing of production animals, mostly cows. Similar estimates as those set out in the previous paragraph indicated that this phenomenon in relation to cow rearing ${ }^{4}$ had a slightly smaller, as in the case of the reduced area of UAA, but also positive impact on the value of the analysed ratio.

\footnotetext{
${ }^{3}$ According to own calculations based on data from Table 3 .

${ }^{4}$ Such conclusions may be drawn, for example, from the study by Czułowska, Skarżyńska and Żekało (2014).
} 
The improved efficiency of national agriculture was also due to the specialisation of production. It limited transaction costs and, in addition, farms with the specialised production did not require such a large number of machinery as farms with the non-specialised production. Therefore, they also incurred lower unit costs for the operation of the tractive force and machinery.

Changes in specialisation are demonstrated by the figures. In 2002-2010, the total number of farms decreased by $24.3 \%$, but the number of those with the specialised production decreased by only $6.5 \%$, while of those with the non-specialised production decreased by $47.3 \%$.

In addition, medium-sized and larger farms, covering 18-19\% of the total number of farms in the country, absorbed innovations bringing technical, biological, marketing and management progress (Karwat-Woźniak, 2013; Józwiak, Kagan and Mirkowska, 2012). However, estimates showed that farms introducing innovation held more than half of the utilised agricultural area of the country. The implementation of innovation led to the increased national agricultural efficiency ratio, but it was not possible to determine the size of this impact.

The above-information shows that a number of factors determined the improvement in the Polish agricultural efficiency ratio in the period prior to and in the year of accession, with most of them continuing the impact in the post-accession period.

In fact, it has been established, based on relevant data and using the same method of calculation as for Table 5, that between 2005 and 2007, and between 2010 and 2012 the number of non-drifting and economically active farms increased by 35 thousand, i.e. by $33.1 \%$. This was less by as many as 31 percentage points than in the previous analysed period, i.e. in 1999-2007. These figures are confirmed in the results determined on the basis of another reasoning ${ }^{5}$. In 2002-2007, the number of farms with an area of 30 ha of UAA or more was growing by 2,350, on an annual average basis, while in 2007-2013 this growth rate was lower by $19.8 \%$. Therefore, the number of such farms was growing by 1,885 on an annual average basis.

The phenomenon of reducing the growth rate in the number of larger and, as shown above, more effective farms was probably due to two reasons. One of them is the degression of rates of some subsidies for larger area farms, while the other is the unstable nationale land lease policy. In 2002-2007, the State Treasury Agricultural Property Agency, on an annual average basis, leased and sold 205.7 thousand ha, but only 113.0 thousand ha in 2008-2013 (Rynek ziemi..., 2016). Farms approaching the limit, whose exceeding could result in the degression of subsidy rates, refrained from increasing the utilised agricultural area, and when they were not threatened by the degression of rates, they purchased land so as to avoid losses caused by the unstable state of land lease policy. The purchase of land reduced the possibilities of investing in more profitable economic undertakings.

Moreover, the reduced animal population was also mentioned previously. Only in 2010-2015, every sixth producer quit the livestock production. This often resulted in an insufficient level of organic fertilisation of arable land and, consequently,

\footnotetext{
${ }^{5}$ The following studies were used for this purpose: GUS (2003); GUS (2008); GUS (2012a); GUS (2014a).
} 
a decrease in the soil fertility (Zieliński, 2012). However, it was not possible to assess the extent to which this phenomenon impacted the value of the analysed index on a national scale, as some farms without the livestock production used various substitutes for manure, and in some cases this substitution was full.

The improvement in the value of the analysed ratio, resulting from the increased number of farms that were larger and economically active, in the post-accession period was, therefore, lower than before accession, and in addition it was limited by the decreased soil productivity due to the fact that some farms ceased breeding animals. This was probably not the only factor resulting in the decreased value of the national agricultural efficiency ratio after accession. Previously, based on analysis of the figures from Table 4, it was noted that as from 2005 the growth rate of the analysed index has slowed down to the extent which even indicated its slight downward trend. The year in which the trend changed indicates that the described phenomenon should be associated with the fact that Poland became a member of the European Union.

The existence of a relation between subsidies to farmers and income from their farms was probably indicated for the first time by Latruffe, a scientific worker at the Department of Agricultural Economics INRA in Rennes, France (Józwiak, 2008). When analysing income of a specific group of French farms, she came to a conclusion that subsidies had a negative effect on the efficiency of farms, but were conducive to their better equipping with technical means of production.

The above-quoted author, this time working in a team (Latruffe, Bravo-Ureta, Carpentier, Desjeux and Moreira, 2017), has recently specified and broadened the scope of her opinion. In analysing farms specialised in the milk production in 1990-2007 in eight EU countries, she concluded that the impact of subsidies on the efficiency was positive only in two countries (Spain and Portugal), in two it was negative (Belgium, the United Kingdom), and in other (Denmark, Germany, France and Ireland) it was impossible to determine any impact. The conclusion of the quoted study is that making direct payments to agricultural producers independent of the production volume, as introduced in 2003, has weakened the impact of subsidies on the technical efficiency of production. However, this conclusion does not answer the question of why a specific policy change in the individual countries has a different impact on farms with the same production profile?

In analysing the quoted results, it should be remembered that in the last two results of the studies, the so-called technical efficiency was analysed, whereas in the present article analysis relates to the economic efficiency measured in a different way.

The analysed phenomenon also raised interest in Poland (Bezat-Jarzębowska, Rembisz and Sielska, 2012). The research team assumed that agricultural producers, when making economic decisions, are also guided by specific agricultural policy instruments, such as, e.g. rates of direct subsidies. Thus, a question arose if this is done at the expense of striving for improving the production efficiency and, in particular, improving the labour productivity as a primary source of income growth. The model-based finding showed that transfers with the use of prices and payments increase agricultural income and further stabilise it, thus improv- 
ing the labour productivity. However, the above-quoted authors add that the effect of the subsidy "... may be that they do not force to improve this performance as a primary source of income of agricultural producers" (Bezat-Jarzębowska et al., 2012, p. 54). They believe that the trueness of this finding is evidenced by the share of subsidies in agricultural income of farms: with predominant crop production, with predominant livestock production and with mixed production. This share was growing in 2004-2009.

However, the figures raise doubt. In 2009, the nominal amount of subsidies was higher than in 2004 by about $112 \%$ and, therefore, not just the actions taken by the agricultural producers, but also the change in the subsidies resulted in the increased share of subsidies in income. It results from the above that the actions taken by the agricultural producers did not have such a deep impact as suggested by authors of the cited study.

Both the study of Latruffe et al. (2017) and the study of Bezat-Jarzębowska et al. (2012) show that the agricultural efficiency is associated with the pursued common agricultural policy. However, from the former we can conclude on a possibility of a decrease in this efficiency, while from the other we can draw a deterministic conclusion that subsidies themselves, irrespective of their type, result in the decreased efficiency. These differences may result from the difference between the common agricultural policy implemented in the countries, which joined the European Union in 2004, and that implemented in the countries of the so-called old Union (EU-15).

The impact of subsidies on the national agricultural efficiency is addressed in the paper by Józwiak, Niewęgłowska and Jabłoński (2013). The authors pointed out the impact of costs of implementing the cross-compliance principle on costs incurred by national agriculture in this respect, as well as on its income, and, consequently, also on the efficiency.

The cross-compliance principle means the requirements to be met by agricultural producers making use of direct payments offered under the Common Agricultural Policy (CAP). Since the year of accession, Polish farms have been obliged to keep their land in good agricultural condition. In 2009, an additional obligation to register production animals and protect the environment was introduced, while in 2011 - the requirement to control the health of animals and crops as well as the obligation to notify certain diseases to the relevant authorities. Then in 2013 the requirement to create conditions providing the welfare of animals was introduced.

The above-quoted authors estimated additional ${ }^{6}$ costs related to the implementation of the cross-compliance principle (purchase of services and materials, own materials and work performed using own equipment, and depreciation of fixed assets) and a reduction, for the same reason, in the value of the production obtained. On this basis, it was established that if the cross-compliance principle had not been in force, agricultural income would have been in $2013^{7}$ higher by PLN 0.7 billion,

\footnotetext{
${ }^{6}$ Some of these costs were estimated using the expert method.

${ }^{7}$ The accounts in the quoted study were made according to the prices of 2009. They were converted to the prices of 2013 using the price change indicators for agricultural products sold and the prices of goods and services purchased by individual agricultural producers. The data from the following studies: GUS (2014b);
} 
and indirect consumption costs would have been lower by PLN 2.3 billion. Using these figures and the figures from Table 3, concerning the situation in 2013, it was established that income would have been PLN 90.1 billion (PLN 89.4 billion+PLN 0.7 billion), while costs - PLN 63.4 billion (PLN 66.6 billion-PLN 2.3 billion). The agricultural efficiency index would be 138.8 and not 134.2 as indicated in Table 4 , and thus it would be higher by 4.6 points.

There is, therefore, no doubt that a necessity to observe the cross-compliance principle contributed clearly to inhibiting the growth rate of the efficiency of Polish agriculture. However, we cannot raise objections to agricultural producers for this reason. After all, direct payments they received were a compensation for observing this principle, but have not been included in the ratios value account, which was used in the text presented for the quantitative assessment of changes in the level of this efficiency.

There was one more phenomenon related to subsidies and having a negative impact on the value of the agricultural efficiency ratio in our country. The 2010 agricultural census (GUS, 2012a) showed that in the middle of that year 386 thousand ha of UAA in Poland (3.0\% of land kept in good agricultural condition) were fallowed. At the moment of carrying out the census, a part of this land was probably prepared for sowing, however, the rest was kept by its owners in a condition enabling access to subsidies. This could be a result of deliberate intention, but a reason could also be sickness, other fortuitous events, farmer's pre-retirement age, etc. However, there is no data allowing to assess the degree of impact of this phenomenon on the value of the analysed ratio.

\section{Summary}

The efficiency of Polish agriculture has been measured using the efficiency ratio being a ratio of income, excluding subsidies to costs of indirect consumption, counted together with depreciation. The efficiency indices for 2000-2013 were calculated in constant prices.

It was concluded that in the four years prior to and in the year of accession, the value of the efficiency ratio grew from the level of 122.5 to the level of 135.6. The increase was, therefore, 13.1 points and its average annual rate was $2.5 \%$. In the nine years after accession, the value of the index was diversified and ranged in the individual years from 133.4 to 136.5. Comparing the extreme values in this period points to a poorly outlined downward trend in the values of the analysed index. This decrease was just more than 1 point, and this means that the average annual rate of decrease was $0.1 \%$.

Several factors determined the growth of the ratio in 2000-2004.

- As a result of the targeted national agricultural policy and funds from the SAPARD and PHARE programmes, co-financed by the European Union, there was a trend with regard to the increased number of larger farms owned by natural persons and characterised by the high production efficiency. This trend

GUS (2015) were used for this purpose. 
has started as early as in the beginning of the 1990s. Those farms implemented innovations bringing different forms of progress and made use of immovable properties left as a result of the disappearance of low-performance farms, mainly state-owned and cooperative.

- The share of farms characterised by the production specialisation was growing. They incurred lower transaction and fixed costs related to the operation of their machinery than farms with mixed production.

- Some farms quit cultivating poor quality farmland and smaller farms quit inefficient small-scale livestock breeding.

During the post-accession period, the majority of the above-mentioned phenomena continued, although to a lower extent, and had a positive effect on the increased national agricultural efficiency ratio. However, there were factors which reduced this growth.

- Direct payment rates for larger farms were reduced. Also, the land lease policy was variable. Both those phenomena decreased the interest of more enterprising agricultural producers in enlarging their farms as a result of land lease. The increase in the share of farms without livestock production led to the decreased productivity of soils as a result of an insufficient level of fertilising with organic fertilisers of animal origin.

- Coverage of Polish farms by the common agricultural policy resulted in a gradual increase in the number of requirements to be met by farms receiving support in a form of grants. This was the obligation to: keep land in good agricultural condition; register production animals and protect the environment; control livestock and crop health; create conditions guaranteeing animal welfare, etc. These costs, combined with the effects of the reduced growth rate in the number of larger and more effective farms, and with the effects of the increased share of farms without the livestock production, significantly reduced the value of the agricultural efficiency index in the post-accession period.

- Moreover, some farms kept land as production-ready. Therefore, they incurred negligible costs, but neither the land nor those costs could bring production results, while farm holders had access to subsidies.

- We cannot also rule out a situation where agricultural producers having an alternative: high production income, high costs and small direct payments vs small income, low costs and high subsidies bringing in total higher income, chose the other option, and this also limited the value of the Polish agricultural efficiency ratio.

Summing up, it can be concluded that the rapid increase in the efficiency of national agriculture in the period of several years prior to and in the year of accession resulted mainly from support from the domestic funds and from great economic freedom, used by farms.

The situation has changed in the years after accession. The amounts of subsidies to farms increased but so did the requirements to be met by beneficiaries of subsidies which applied to the environmental protection and animal welfare. 
The agri-food industry rose the requirements regarding products of agricultural origin. The economic activity of larger farms has been limited by the degression of the rates of aid. In addition, it is likely that some agricultural producers have been mainly focused on making use of subsidies and this phenomenon was accompanied by the decreased interest in improving the efficiency of the conducted agricultural production.

Some arguments contained in the article have been based on estimates. All of them are rationally substantiated, but nevertheless the article should be considered as initial analysis of the issue. 


\section{References}

Abramczuk, Ł., Augustyńska-Grzymek, I., Czułowska, M., Jabłoński, K., Józwiak, W., Skarżyńska, A., Zieliński, M., Ziętara, W., Żekało, M. (2015). Przedsiębiorstwo i gospodarstwo rolne wobec zmian klimatu i polityki rolnej (1). W. Józwiak (ed.). Monografie Programu Wieloletniego 2015-2019, No. 16, Warszawa: IERiGŻ-PIB.

Augustyńska-Grzymek, I., Cholewa, M., Żekało, M. (2011). Produkcja, koszty i dochody z wybranych produktów rolniczych w latach 2009-2010 (wyniki rachunku symulacyjnego). M. Cholewa (ed.). Warszawa: IERiGŻ-PIB.

Bezat-Jarzębowska, A., Rembisz, W., Sielska, A. (2012). Wybór polityki i jej wpływ na decyzje producentów rolnych w ujęciu analitycznym z elementami weryfikacji empirycznej. Program Wieloletni 2011-2014, No. 49, Warszawa: IERiGŻ-PIB.

Czułowska, M., Skarżyńska, A., Żekało, M. (2014). Wyniki ekonomiczne wybranych produktów rolniczych w 2012 roku. A. Skarżyńska (ed.). Warszawa: IERiGŻ-PIB.

Gomułka, J., Guzewicz, W., Józwiak, W., Niewęgłowska, G., Zdzieborska, M. (2003). Ewolucja gospodarstw rolnych w latach 1996-2002. Warszawa: GUS.

GUS (1997). Rocznik Statystyczny 1997. Warszawa: GUS.

GUS (2003). Systematyka i charakterystyka gospodarstw rolnych 2002. Warszawa: GUS.

GUS (2008). Charakterystyka gospodarstw rolnych w 2007 r. Warszawa: GUS.

GUS (2011). Powszechny Spis Rolny 2010. Warszawa: GUS.

GUS (2012a). Charakterystyka gospodarstw rolnych w 2011 r. Warszawa: GUS.

GUS (2012b). Narodowy Spis Powszechny Ludności i Mieszkań 2011. Warszawa: GUS.

GUS (2012c). Rolnictwo w 2011 r. Warszawa: GUS, Departament Rolnictwa.

GUS (2014a). Charakterystyka gospodarstw rolnych w 2013 r. Informacje i Opracowania Statystyczne. Warszawa: GUS.

GUS (2014b). Rolnictwo w 2013 r. Warszawa: GUS, Departament Rolnictwa.

GUS (2015). Rolnictwo w 2014 r. Warszawa: GUS, Departament Rolnictwa.

GUS (2017a). Rocznik Statystyczny Rolnictwa 2016. Warszawa: GUS.

GUS (2017b). Rocznik Statystyczny Rzeczpospolitej Polskiej 2016. Warszawa: GUS.

GUS (2017c). Rolnictwo w 2016 r. Warszawa: GUS, Departament Rolnictwa.

IERiGŻ (2000). Wyniki rachunkowości rolnej gospodarstw indywidualnych 1999. Warszawa: IERiGŻ.

Józwiak,W. (2008). Reminiscencje z pobytu w INRA.Zagadnienia Ekonomiki Rolnej, No. 1(314), pp. 79-85.

Józwiak, W. (2012). Polskie rolnictwo i gospodarstwa rolne w pierwszej i drugiej dekadzie XXI wieku. Program Wieloletni 2011-2014, No. 53, Warszawa: IERiGŻ-PIB.

Józwiak, W., Kagan, A., Mirkowska, Z. (2012). Innowacje w polskich gospodarstwach rolnych, zakres ich wdrażania i znaczenie. Zagadnienia Ekonomiki Rolnej, No.3(332), pp. 3-27.

Józwiak, W., Niewęgłowska, G., Jabłoński, K. (2013). Koszty realizacji zasady wzajemnej zgodności a dochody w rolnictwie polskim. In: J.S. Zegar (ed.). Z badań nad rolnictwem społecznie zrównoważonym (20). Wybrane zagadnienia zrównoważonego rozwoju rolnictwa (s. 123-138). Program Wieloletni 2011-2014, No. 93. Warszawa: IERiGŻ-PIB.

Józwiak, W. (2014). Rozwój krajowych przedsiębiorstw rolnych osób fizycznych w świetle idei „spirali wzrostu”. Program Wieloletni 2011-2014, No. 113. Warszawa: IERiGŻ-PIB.

Karwat-Woźniak, B. (2013). Zmiany $w$ formach sprzedaży produktów rolnych $w$ gospodarstwach indywidualnych. Warszawa: IERiGŻ-PIB. 
Latruffe, L., Bravo-Ureta, B.E., Carpentier, A., Desjeux, Y., Moreira, V.H. (2017). Subsydies and technical efficency in agriculture: evidence from European dairy farms. American Journal of Agricultural Economics, vol. 99, No. 3, pp. 783-799.

Rachunki Ekonomiczne dla Rolnictwa (RER). Eurostat.

Rynek ziemi rolniczej. Stan i perspektywy (2016). Analizy Rynkowe, No. 19. Warszawa: IERiGŻ-PIB, ANR i MRiRW.

Zieliński, M. (2012). Efekty gospodarstw specjalizujących się w uprawie zbóż, roślin oleistych i białkowych sekwestrujących $\mathrm{CO}_{2}$. Roczniki Naukowe SERiA, vol. XIV, z. 5, pp. 219-223. 
Annex I

Value of revenues from the Polish agriculture in 1998-2015 expressed in nominal and constant prices

\begin{tabular}{|c|c|c|c|c|c|}
\hline \multirow{2}{*}{ Years } & \multicolumn{3}{|c|}{ Agricultural revenues } & \multicolumn{2}{|c|}{$\begin{array}{c}\text { Indexes of changes } \\
\text { in agricultural revenues } \\
\text { expressed in constant prices }\end{array}$} \\
\hline & $\begin{array}{l}\text { In nominal } \\
\text { prices } \\
\text { in PLN billion }\end{array}$ & $\begin{array}{l}\text { Indexes of } \\
\text { conversion into } \\
\text { constant prices }\end{array}$ & $\begin{array}{l}\text { In constant } \\
\text { prices } \\
\text { in PLN billion }\end{array}$ & $1998=100$ & $\begin{array}{l}\text { Previous } \\
\text { year=100 }\end{array}$ \\
\hline 1998 & 48.8 & 1.772 & 86.5 & 100.0 & - \\
\hline 1999 & 45.7 & 1.753 & 80.1 & 92.6 & 92.6 \\
\hline 2000 & 49.7 & 1.529 & 76.0 & 87.8 & 94.9 \\
\hline 2001 & 54.2 & 1.462 & 79.2 & 91.6 & 104.2 \\
\hline 2002 & 51.0 & 1.581 & 80.6 & 93.2 & 101.8 \\
\hline 2003 & 51.3 & 1.685 & 86.4 & 99.9 & 107.2 \\
\hline 2004 & 60.9 & 1.446 & 88.1 & 101.8 & 102.0 \\
\hline 2005 & 56.8 & 1.465 & 83.2 & 96.2 & 94.4 \\
\hline 2006 & 58.4 & 1.417 & 82.7 & 95.6 & 99.4 \\
\hline 2007 & 71.8 & 1.257 & 90.2 & 104.3 & 109.1 \\
\hline 2008 & 72.6 & 1.219 & 88.5 & 102.3 & 98.1 \\
\hline 2009 & 70.3 & 1.247 & 87.7 & 101.4 & 99.1 \\
\hline 2010 & 73.9 & 1.147 & 84.8 & 98.0 & 96.7 \\
\hline 2011 & 89.5 & 0.966 & 86.5 & 100.0 & 102.0 \\
\hline 2012 & 93.8 & 0.927 & 86.9 & 100.5 & 100.5 \\
\hline 2013 & 96.9 & 0.959 & 92.9 & 107.4 & 106.9 \\
\hline 2014 & 95.1 & 0.968 & 92.1 & 106.5 & 99.1 \\
\hline 2015 & 91.2 & 1.000 & 91.2 & 105.4 & 99.0 \\
\hline
\end{tabular}

Source: as for Table 2 in the body of the paper. 
Costs of intermediate consumption in the Polish agriculture in 1998-2015

Annex II (less depreciation costs) expressed in nominal and constant prices

\begin{tabular}{|c|c|c|c|c|c|}
\hline \multirow{2}{*}{ Years } & \multicolumn{3}{|c|}{ Costs of intermediate consumption } & \multicolumn{2}{|c|}{$\begin{array}{l}\text { Indexes of changes in costs } \\
\text { of intermediate consumption } \\
\text { expressed in constant prices }\end{array}$} \\
\hline & $\begin{array}{l}\text { In nominal } \\
\text { prices } \\
\text { in PLN billion }\end{array}$ & $\begin{array}{l}\text { Indexes of } \\
\text { conversion into } \\
\text { constant prices }\end{array}$ & $\begin{array}{l}\text { In constant } \\
\text { prices } \\
\text { in PLN billion }\end{array}$ & $1998=100$ & $\begin{array}{l}\text { Previous } \\
\text { year=100 }\end{array}$ \\
\hline 1998 & 28.9 & 2.140 & 61.8 & 100.0 & - \\
\hline 1999 & 28.2 & 1.994 & 56.2 & 90.9 & 90.9 \\
\hline 2000 & 31.3 & 1.791 & 56.1 & 90.8 & 99.8 \\
\hline 2001 & 33.0 & 1.680 & 55.4 & 89.6 & 98.7 \\
\hline 2002 & 32.4 & 1.651 & 53.5 & 86.6 & 96.6 \\
\hline 2003 & 33.5 & 1.615 & 54.1 & 87.5 & 101.1 \\
\hline 2004 & 37.9 & 1.487 & 56.4 & 91.2 & 104.2 \\
\hline 2005 & 36.0 & 1.459 & 52.5 & 84.9 & 93.1 \\
\hline 2006 & 37.6 & 1.453 & 54.6 & 88.3 & 104.0 \\
\hline 2007 & 44.7 & 1.372 & 61.3 & 99.2 & 112.3 \\
\hline 2008 & 48.8 & 1.221 & 59.6 & 96.4 & 97.2 \\
\hline 2009 & 46.8 & 1.200 & 56.2 & 90.9 & 94.3 \\
\hline 2010 & 48.0 & 1.155 & 55.4 & 89.6 & 98.6 \\
\hline 2011 & 57.2 & 1.063 & 60.8 & 98.4 & 109.7 \\
\hline 2012 & 59.3 & 0.995 & 59.0 & 95.5 & 97.0 \\
\hline 2013 & 59.8 & 1.004 & 60.0 & 97.1 & 101.7 \\
\hline 2014 & 61.1 & 1.018 & 62.2 & 100.6 & 103.7 \\
\hline 2015 & 60.9 & 1.000 & 60.9 & 98.5 & 97.9 \\
\hline
\end{tabular}

Source: as for Table 2 in the body of the paper. 


\title{
EFEKTYWNOŚĆ FUNKCJONOWANIA \\ ROLNICTWA POLSKIEGO W LATACH 1998-2015
}

\begin{abstract}
Abstrakt
W rolnictwie polskim $w$ kilkuletnim okresie przed akcesja $i$ w roku akcesji odnotowano szybki wzrost efektywności produkcji rolniczej, później natomiast niewielki spadek. W artykule wskazano na przyczyny tego zjawiska. W pierwszym $z$ tych podokresów istniała duża swoboda gospodarcza $i$ nastapił wzrost wsparcia gospodarstw rolnych udzielony głównie ze środków krajowych. W latach po 2004 roku sytuacja uległa zmianie. Wzrosty kwoty środków pomocowych, ale wzrosły też wymogi dotyczace ochrony środowiska, zdrowia konsumentów i dobrostanu zwierzat, jakie musieli spełnić rolnicy bęacy beneficjentami dopłat. Większe gospodarstwa rolne ograniczyły ponadto aktywność gospodarcza z powodu degresji stawek dopłat. Jest poza tym prawdopodobne, że część producentów rolnych nastawiła sie głównie na korzystanie z dopłat, a zjawisku temu towarzyszył spadek zainteresowania poprawa efektywności prowadzonej produkcji rolniczej. Część wywodów zawartych w artykule oparto na szacunkach. Maja one racjonalne uzasadnienia, ale zdaniem autora artykut należy traktować jako wstepną analize tematu.
\end{abstract}

Słowa kluczowe: efektywność, rolnictwo, efektywność produkcji.

Accepted for print: 18.12.2018.

Unless stated otherwise all the materials on the website are available under the Creative Commons Attribution 4.0 International license.

Some rights reserved to the Institute of Agricultural and Food Economics - National Research Institute.

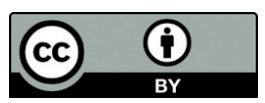

